Article

\title{
Comparing the Nature of Active Sites in Cu-loaded SAPO-34 and SSZ-13 for the Direct Conversion of Methane to Methanol
}

\author{
Karoline Kvande ${ }^{1, * \mathbb{D}}$, Dimitrios K. Pappas ${ }^{1}$, Michael Dyballa ${ }^{1}{ }^{\circledR}$, Carlo Buono ${ }^{1}$, \\ Matteo Signorile $^{2}{ }^{\mathbb{D}}$, Elisa Borfecchia ${ }^{2} \mathbb{D}$, Kirill A. Lomachenko ${ }^{3} \mathbb{B}$, Bjørnar Arstad ${ }^{4}$, \\ Silvia Bordiga ${ }^{2}$, Gloria Berlier ${ }^{2}{ }^{-}$, Unni Olsbye ${ }^{1}$, Pablo Beato $^{5}$ and Stian Svelle ${ }^{1}$ \\ 1 Center for Materials Science and Nanotechnology (SMN), Department of Chemistry, University of Oslo, \\ 1033 Blindern, 0315 Oslo, Norway; dimitrios.pappas@smn.uio.no (D.K.P.); \\ michael.dyballa@itc.uni-stuttgart.de (M.D.); carlo.buono@smn.uio.no (C.B.); \\ unni.olsbye@kjemi.uio.no (U.O.); stian.svelle@kjemi.uio.no (S.S.) \\ 2 Department of Chemistry, NIS Center and INSTM Reference Center, University of Turin, via P. Giuria 7, \\ 10125 Turin, Italy; matteo.signorile@unito.it (M.S.); elisa.borfecchia@unito.it (E.B.); \\ silvia.bordiga@unito.it (S.B.); gloria.berlier@unito.it (G.B) \\ 3 European Synchrotron Radiation Facility, 71 avenue des Martyrs, CS 40220, CEDEX 9, \\ 38043 Grenoble, France; kirill.lomachenko@esrf.fr \\ 4 SINTEF Industry, Department of Process Technology, Forskningsveien 1, 0373 Oslo, Norway; \\ bjornar.arstad@sintef.no \\ 5 Haldor Topsøe A/S, Haldor Topsøes Allé 1, DK-2800 Kgs. Lyngby, Denmark; pabb@topsoe.com \\ * Correspondence: karoline.kvande@smn.uio.no; Tel.: +47-228-55-535
}

Received: 20 December 2019; Accepted: 3 February 2020; Published: 5 February 2020

check for updates

\begin{abstract}
On our route towards a more sustainable future, the use of stranded and underutilized natural gas to produce chemicals would be a great aid in mitigating climate change, due to the reduced $\mathrm{CO}_{2}$ emissions in comparison to using petroleum. In this study, we investigate the performance of Cu-exchanged SSZ-13 and SAPO-34 microporous materials in the stepwise, direct conversion of methane to methanol. With the use of X-ray absorption spectroscopy, infrared (in combination with $\mathrm{CO}$ adsorption) and Raman spectroscopy, we compared the structure-activity relationships for the two materials. We found that SSZ-13 performed significantly better than SAPO-34 at the standard conditions. From $\mathrm{CH}_{4}-\mathrm{TPR}$, it is evident that SAPO-34 requires a higher temperature for $\mathrm{CH}_{4}$ oxidation, and by changing the $\mathrm{CH}_{4}$ loading temperature from 200 to $300{ }^{\circ} \mathrm{C}$, the yield $(\mu \mathrm{mol} / \mathrm{g})$ of SAPO-34 was increased tenfold. As observed from spectroscopy, both three- and four-fold coordinated $\mathrm{Cu}$-species were formed after $\mathrm{O}_{2}$-activation; among them, the active species for methane activation. The $\mathrm{Cu}$ speciation in SAPO-34 is distinct from that in SSZ-13. These deviations can be attributed to several factors, including the different framework polarities, and the amount and distribution of ion exchange sites.
\end{abstract}

Keywords: methane; methanol; zeolite; chabazite; spectroscopy; TPR

\section{Introduction}

Methane has become increasingly abundant as a carbon resource in recent years, and can be found in numerous sources [1]. The utilization of methane for chemicals, however, is rather complicated, due to the high stability of the molecule. The main method for converting methane in industry today is with the steam reforming reaction to produce synthesis gas. Synthesis gas can further be converted into valuable products, such as olefins, alcohols and ethers [2,3]. Nevertheless, the production of 
this intermediate gas requires large facilities, due to the economy of scale, and transportation from remote areas is costly. These restrictions lead to the flaring of large amounts of associated petroleum gas. Flaring of methane causes more than 300 million tons of $\mathrm{CO}_{2}$ to be released into the atmosphere every year. The World Bank has set in motion a "zero routine flaring initiative" to eliminate all routine flaring by the end of 2030 [4]. It is therefore of high interest to find a direct route for converting methane into liquid products on-site for the utilization of such stranded gas. Some promising liquids for further utilization are methanol and dimethyl ether (DME). Methanol may be used directly as a gasoline additive and for electric power generation; it is also an important starting material in the chemical industry for the production of highly demanded products, such as plastic, pharmaceuticals and plywood [5]. DME is usually made from methanol dehydration, and is an important compound for the future. DME has been extensively investigated the last decades as a more sustainable alternative to regular diesel fuel and LPG (both products from oil refining). This is because the properties of DME are quite similar to those of diesel and LPG, and therefore, only a few modifications are necessary to the already existing infrastructure [6,7]. One of the most promising routes currently being explored by the scientific community is the direct conversion of methane to methanol (DMTM). Many paths have been proposed and tested. The main problem, however, is the challenge of overcoming the over-oxidation of methanol to $\mathrm{CO}_{x}[3]$.

In nature, methane monooxygenase (MMO) enzymes convert methane directly into methanol under ambient conditions over active $\mathrm{Fe}$ or $\mathrm{Cu}$ metal sites [8]. Taking inspiration from these enzymes, metal-exchanged zeolites have been tested extensively for DMTM in a stepwise, stoichiometric reaction process. It has been demonstrated that a wide variety of zeolites (e.g., MOR [9-13], CHA [14,15], MFI $[16,17])$ are able to form stable and unique metal-oxo sites. In 2005, Groothaert et al. reported a stepwise reaction procedure working with $\mathrm{Cu}-\mathrm{ZSM}-5$ and $\mathrm{Cu}-\mathrm{MOR}$ zeolites activated in $\mathrm{O}_{2}$ for the direct conversion of methane to methanol [16]. The reaction procedure usually consists of three steps. First, an activation step at elevated temperatures (around $500^{\circ} \mathrm{C}$ ) is performed with an oxidant (e.g., $\mathrm{N}_{2} \mathrm{O}, \mathrm{O}_{2}$ ) to create the metal-oxo sites. Subsequently, the temperature is lowered, before the methane is reacted over the active sites. Last, methanol is extracted by sending steam through the reactor isothermally, or by using a polar liquid solvent at room temperature (RT). The highest productivity achieved at atmospheric pressure thus far is $0.47 \mathrm{~mol}_{\mathrm{MeOH}} / \mathrm{mol}_{\mathrm{Cu}}$, for a Cu-MOR zeolite $[18,19]$. If a dinuclear active site is assumed, the theoretical limit is 0.5 . It has been shown that there are a number of factors that influence the productivity and yield of methanol in the reaction, with some of the more important being the process parameters as well as the $\mathrm{Cu}$ speciation in the zeolite and the subsequent reducibility $[14,19-24]$.

The high-silica, chabazite zeolite, SSZ-13, has been tested extensively for the reaction. However, the literature is scarce on the isostructural zeotype material SAPO-34. To the best of our knowledge, only Wulfers et al. have tested this material in the stepwise DMTM conversion [15]. Since SAPO-34 is an industrial scale catalyst for the conversion of methanol to olefins (MTO) [25], and is widely investigated as a $\mathrm{Cu}$-loaded catalyst in $\mathrm{NH}_{3}$-assisted selective catalytic reduction $\left(\mathrm{NH}_{3}-\mathrm{SCR}\right)$ of $\mathrm{NO}_{x}$ [26], it became clear that a more extensive, comparative study on the reactivity of these materials in the DMTM-conversion would be of high interest.

The CHA framework consists of double six-membered rings (D6R) stacked in an ABC-sequence and interconnected with four membered rings (4MR). The resulting cages can be considered catalytic converters, which are interconnected with eight-membered ring (8MR) windows (Figure 1a). CHA is an ideal framework to work with, as the framework only has one crystallographically unique T-site [27,28]. Four different ion exchange sites have been determined in the CHA framework. Three of them point towards the centre of the $8 \mathrm{MR}$-window, while one is in a more constrained position pointing into the D6R (Figure 1b) [29]. 

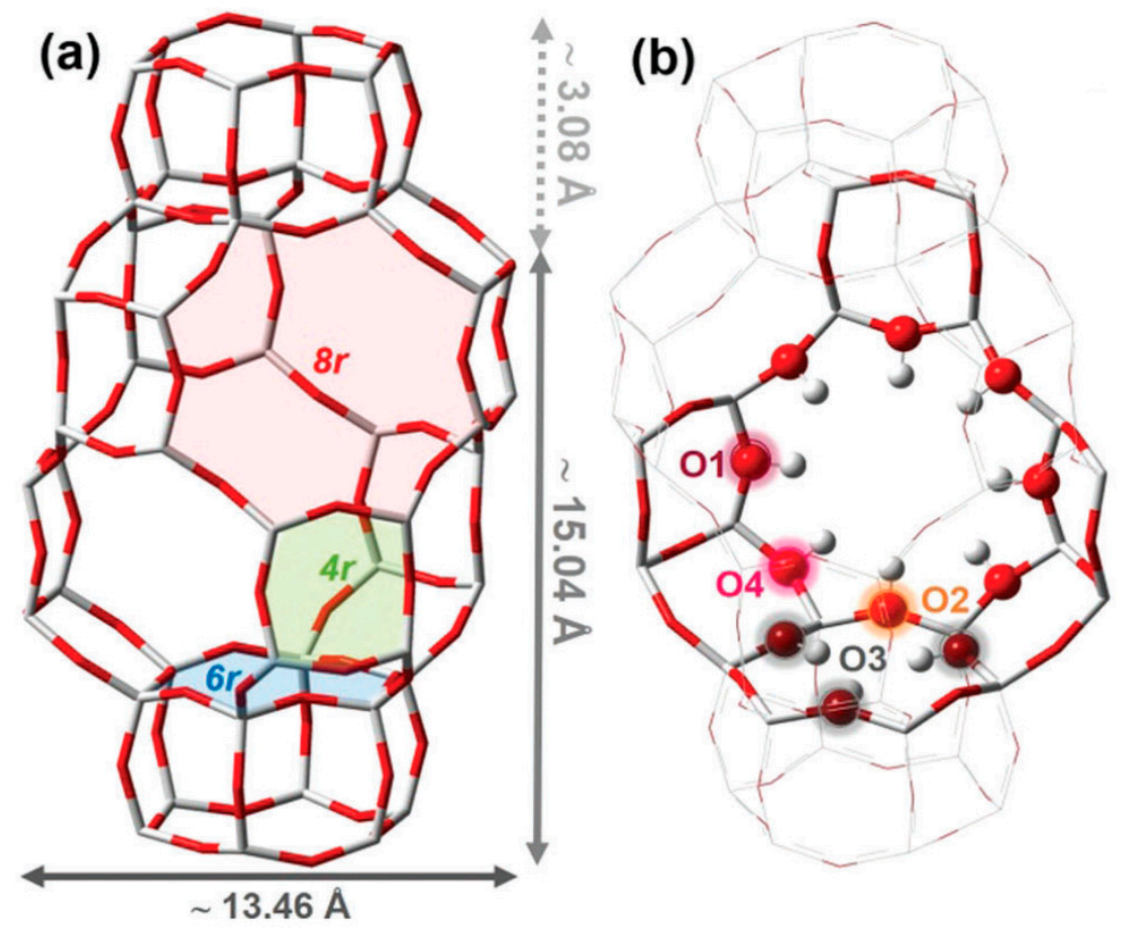

Figure 1. Representation of the CHA framework. The coloured areas in (a) marks the three different ring types (4MR, D6R and 8MR) surrounding the cages. (b) illustrates the four different O-sites in the framework. Colour code: grey: Si (SSZ-13) or alternating Al and P (SAPO-34), red: O, orange: Al (SSZ-13) or Si (SAPO-34). Adapted from Borfecchia et al. [29].

In SSZ-13, the amount of ion exchange sites (i.e., Brønsted acid sites) is determined by the Al-content. Conversely, the ion exchange sites in SAPO-34 are correlated to the amount of Si in the framework. In SAPO-34, Si incorporation may follow different substitution mechanisms (SM). There are two main mechanisms, where one leads to the formation of one Brønsted acid site per Si (SM2), while the other leads to a Si-rich patch (SM3) [30]. The two mechanisms are illustrated in Figure 2. Due to the different paths, the amount of $\mathrm{Si}$ in the framework will most likely not correlate directly to the amount of ion exchange sites. Whether the Si mostly follows the SM2, SM3, or a combination of these depends on the synthesis procedure [31].
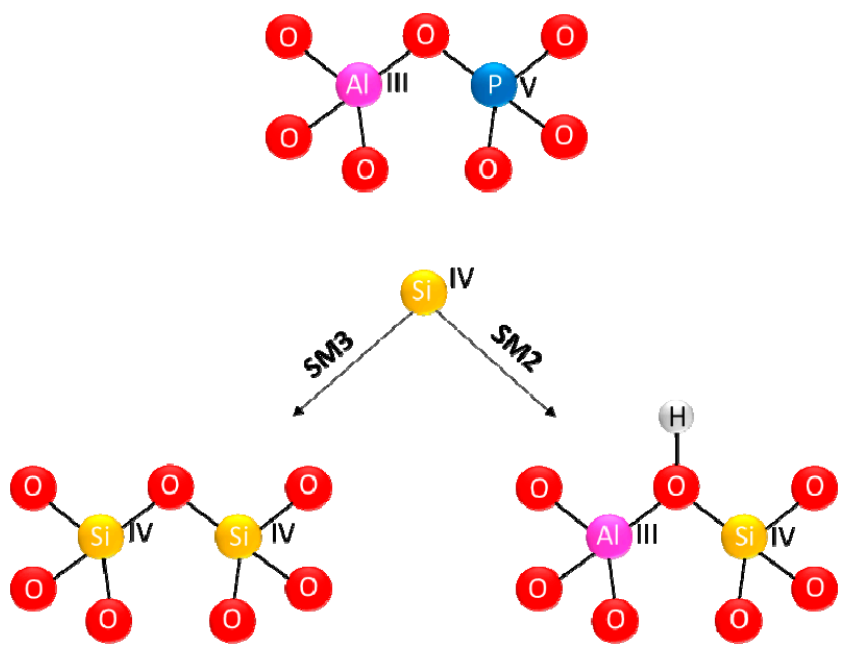

Figure 2. Scheme of the SM2 and SM3 mechanisms for Si substitution into the SAPO-34 framework. O is presented in red, $\mathrm{Al}$ in purple, $\mathrm{Si}$ in yellow, and $\mathrm{P}$ in blue. 
Pappas et al. reported a thorough investigation of Cu-exchanged SSZ-13 for the DMTM reaction [14]. They combined characterization data from several spectroscopic techniques, together with a detailed study of the process conditions to pinpoint structure-activity relations [14]. A set of parameters were found to represent the optimal conditions for the conversion of methane $\left(8 \mathrm{~h}\right.$ in $\mathrm{O}_{2}$ $\left(500^{\circ} \mathrm{C}\right), 6 \mathrm{~h}$ in $\mathrm{CH}_{4}\left(200^{\circ} \mathrm{C}\right), \mathrm{H}_{2} \mathrm{O}$-assisted extraction $\left(200^{\circ} \mathrm{C}\right)$ ).

In the current work, two Cu-SAPO-34 samples, with low and high $\mathrm{Cu}$ loading, were tested for the direct conversion of methane to methanol. When investigating the DMTM conversion, methanol and DME should both be regarded as important products, and therefore, the reported methanol activity in this study is given as the sum of methanol and DME observed in the extraction feed $\left(\mathrm{MeOH}=\mathrm{CH}_{3} \mathrm{OH}\right.$ $\left.+2 \times\left(\mathrm{CH}_{3}-\mathrm{O}-\mathrm{CH}_{3}\right)\right)$. Due to practical reasons, the standard experiments performed in this study had a shortened $\mathrm{CH}_{4}$-loading time of $3 \mathrm{~h}$. All other parameters were kept equal to the optimal conditions reached by Pappas et al. [14]. These results were then compared to a high loaded Cu-SSZ-13 material. Furthermore, IR, Raman and XAS spectroscopies, as well as $\mathrm{CH}_{4}$-TPR have been employed to obtain a deeper understanding of the differences between the two isostructural CHA-zeolites, with respect to the nature of the $\mathrm{Cu}$-sites and the effect of framework acidity.

\section{Results and Discussion}

\subsection{Physicochemical Characterization}

The $\mathrm{Cu}$ exchanged samples were prepared from the $\mathrm{H}$-form of the materials. The introduction of $\mathrm{Cu}$ was performed with Liquid Ion Exchange (LIE), as described in the experimental section. In SAPO-34, it was not feasible to reach a high degree of $\mathrm{Cu}$ incorporation, and the highest amount of $\mathrm{Cu}$ obtained was $1.58 \mathrm{wt} \%(\mathrm{Cu} / \mathrm{Si}=0.25)$. This amount was reached after three consecutive exchanges according to a method reported by Vennestrøm et al. [32]. The calcining step between each exchange should help the migration of $\mathrm{Cu}$ ions from the surface into the crystal.

Nomenclature and physicochemical characterization data, such as compositional information, $\mathrm{N}_{2}$-physisorption data, and water content are reported in Table S1 in the supporting information (SI). Scanning Electron Microscopy (SEM) (Figure S1) and X-ray Diffraction (XRD) (Figures S2 and S3) analyses were performed for all the (Cu-)SAPO-34 samples and the results are reported in the SI. SEM-images and XRD pattern of (Cu-)SSZ-13 have been reported previously [14]. No extra CuO phase is observed in the materials, indicating that they are free of any large $\mathrm{CuO}$ agglomerates and that the $\mathrm{Cu}$ exchange took place properly.

\subsection{Direct Methane to Methanol Conversion}

The exchanged Cu-SAPO-34 and SSZ-13 materials were investigated for the direct conversion of methane to methanol. The test procedure is described in the experimental section (Test \#1). The protocol is based on optimal conditions reported in a previous study by Pappas et al. [14] on Cu-SSZ-13 materials for the same reaction. The results are reported in Figure 3. On the left, the total yield of methanol $\left(\mathrm{mol}_{\mathrm{MeOH}} / \mathrm{g}_{\text {zeolite }}\right)$ is shown as a function of the $\mathrm{Cu}$-content. The right panel shows the productivity, where the total amount of methanol is normalized to the $\mathrm{Cu}$-content. Minor fractions of $\mathrm{CO} / \mathrm{CO}_{2}$ were observed in the effluent during methane loading and $\mathrm{H}_{2} \mathrm{O}$-assisted extraction.However, the yield of the $\mathrm{CO}_{\mathrm{x}}$ species has not been reported in this study due to high uncertainties in the obtained $\mathrm{CO}_{\mathrm{x}}$ values. From the results reported in Figure 3, it is evident that the $\mathrm{Cu}$-loaded SSZ-13 outperforms the $\mathrm{Cu}-\mathrm{SAPO}-34$ materials in the reaction. This is in line with previous results obtained for the DMTM conversion over Cu-SSZ-13 and SAPO-34, reported by Wulfers et al. [29]. Another interesting observation is that a higher loading of $\mathrm{Cu}$ in SAPO-34 does not increase the yield of methanol. Indeed, a slightly higher productivity is seen for the low loaded sample, as observed in the right panel of Figure 3. These results indicate that it is only a small fraction of the exchanged $\mathrm{Cu}$ in SAPO-34 that contributes as active sites for methane conversion, and that an increase in $\mathrm{Cu}$-content does not lead to an increased amount of these active sites. A blind test was performed on both $\mathrm{Cu}$-free SAPO-34 
and SSZ-13 under the same reaction conditions, and no methanol was detected in the effluent. This confirms that the small amount of methanol observed for Cu-SAPO-34 in the tests is significant.

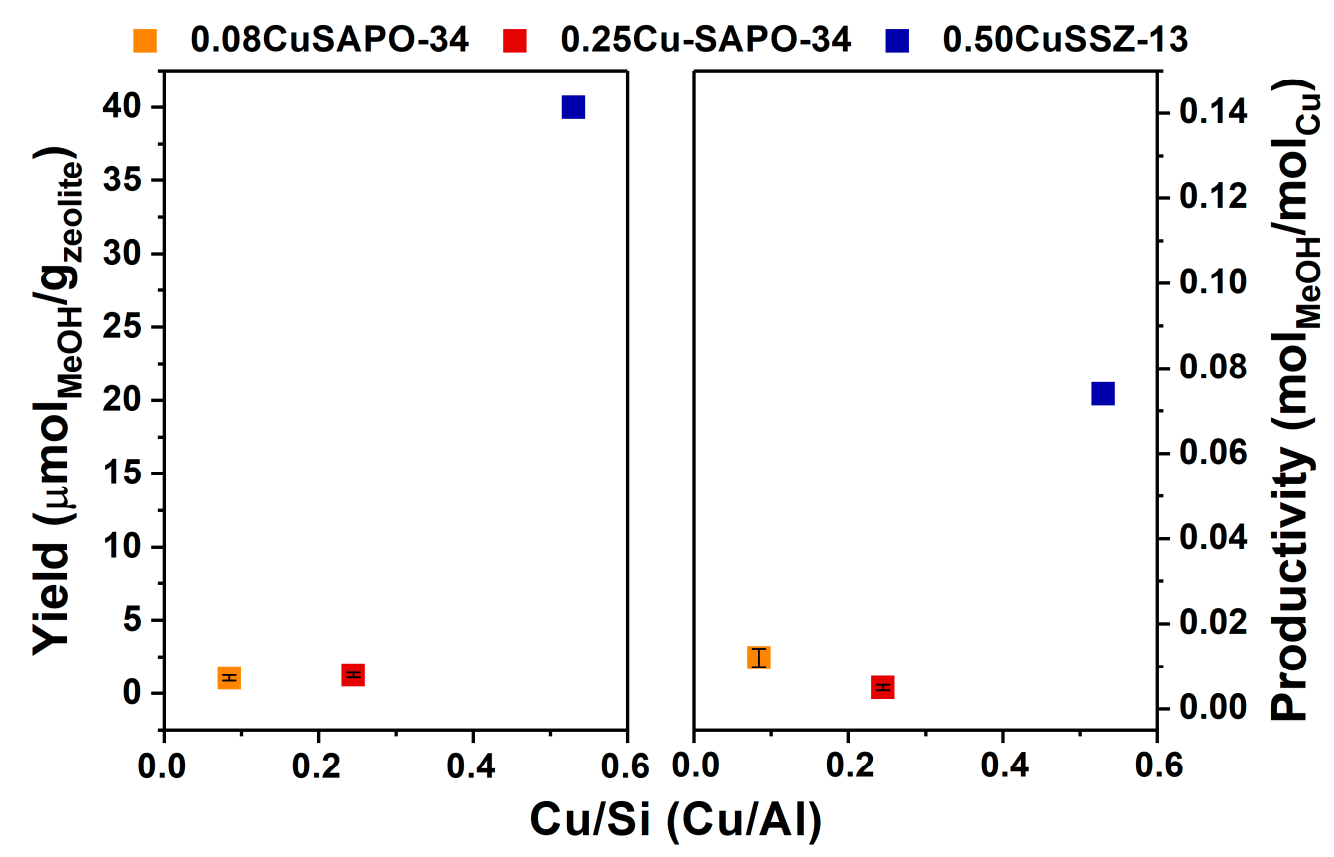

Figure 3. Representation of the performance of 0.08CuSAPO-34 (orange), 0.25CuSAPO-34 (red) and 0.50CuSSZ-13 (blue) at identical reaction conditions (Table 1). The panel on the left shows $\mathrm{CH}_{3} \mathrm{OH}$ yield per gram of zeolite. The panel on the right gives the $\mathrm{CH}_{3} \mathrm{OH}$ yield normalized to the $\mathrm{Cu}$ content $\left(\mathrm{molCH} \mathrm{H}_{3} \mathrm{OH} / \mathrm{molCu}\right)$. The estimated error from DMTM conversion over Cu-SAPO-34 is shown as black error bars inside the squares.

Due to the structural similarities between the materials, the difference in performance was unexpected. A deeper investigation with various spectroscopic techniques (IR, Raman and in situ XAS) was therefore performed, with the aim of elucidating the $\mathrm{Cu}$-speciation of the materials.

\subsection{Utilizing Spectroscopy to Investigate the $\mathrm{Cu}$-Speciation}

\subsubsection{Investigating the $\mathrm{Cu}(\mathrm{II})_{\mathrm{x}} \mathrm{O}_{\mathrm{y}}$ Sites with Raman Spectroscopy}

Resonance Raman (rRaman) spectra of activated, sealed capillaries were collected with a blue laser $(488 \mathrm{~nm})$ at RT. The resulting spectra of hydrated and activated 0.25Cu-SAPO-34 (red) and 0.50Cu-SSZ-13 (blue) are shown in Figure 4. It is clear from the figure that a new set of bands arise in the spectra when the material has been activated at high temperatures in static air. These bands are correlated to $\mathrm{Cu}(\mathrm{II})_{\mathrm{x}} \mathrm{O}_{\mathrm{y}}$ species that are resonantly enhanced by the blue laser. Frequencies and reasonable assignments are summarized in Table S2. The assignment of the $\mathrm{Cu}(\mathrm{II})_{\mathrm{x}} \mathrm{O}_{\mathrm{y}}$-species in the Cu-SSZ-13 material has been made previously [14]. For SAPO 34, the assignments presented below are based on previous observations on Cu-SSZ-13, Cu-ZSM-5 and other compounds [14,17]. The band at $812 \mathrm{~cm}^{-1}$, together with the shoulders found at 524 and $587 \mathrm{~cm}^{-1}$ have been assigned to a three-fold coordinated dicopper species $\left[\mathrm{Cu}\left(\text { trans }-\mu-1,2-\mathrm{O}_{2}\right) \mathrm{Cu}\right]^{2+}$, which is based on bands appearing at similar positions in Cu-loaded SSZ-13 (830, 510 and $\left.580 \mathrm{~cm}^{-1}\right)$, observed by Pappas et al. and Ipek et al. [14,33]. It is worth noting that the resonance enhancement of this dicopper-species is very clear in Cu-SSZ-13, while in $\mathrm{Cu}-\mathrm{SAPO}-34$, the features are only observed as minor contributions. The strongest band in $\mathrm{Cu}-\mathrm{SAPO}-34$, at $549 \mathrm{~cm}^{-1}$ is assigned to the symmetric vibration of $\mathrm{Cu}-\mathrm{O}$ in a side-on superoxo $\mathrm{Cu}$ (II) species. The corresponding $v(\mathrm{O}-\mathrm{O})$ mode of the same species is observed at $1006 \mathrm{~cm}^{-1}$. These bands are assigned by analogy with the rRaman results by Solomon and co-workers, reporting signals at 554 and $1043 \mathrm{~cm}^{-1}$ for $\mathrm{Cu}$-superoxo species in homogeneous model compounds [34]. Pappas et al. 
also found bands indicating the presence of side-on superoxo $\mathrm{Cu}(\mathrm{II})$ and mono- $\mu$-oxo dicopper(II) $\left([\mathrm{Cu}-(\mu-\mathrm{O})-\mathrm{Cu}]^{2+}\right)$ in $\mathrm{Cu}-\mathrm{SSZ}-13$ [14]. No bands corresponding to these species were found to be present in $\mathrm{Cu}-\mathrm{SAPO}-34$. The assignment of the observed bands indicates that there are significant differences between SSZ-13 and SAPO-34 with respect to the types of $\mathrm{Cu}(\mathrm{II})_{\mathrm{x}} \mathrm{O}_{\mathrm{y}}$ complexes formed in the materials, even though they possess the same CHA framework topology. Pappas et al. have suggested that three-fold coordinated $\mathrm{Cu}$ (II) sites may be the most favourable geometric sites for methane conversion, which is the most pronounced species appearing in SSZ-13 (trans- $\mu$-oxo dicopper(II)) [14]. The more pronounced species appearing in Cu-SAPO-34 is a monomeric site with a four-fold coordination (side-on superoxo $\mathrm{Cu}(\mathrm{II})$ ), and these sites are assumed to be less active for $\mathrm{CH}_{4}$-activation [14].

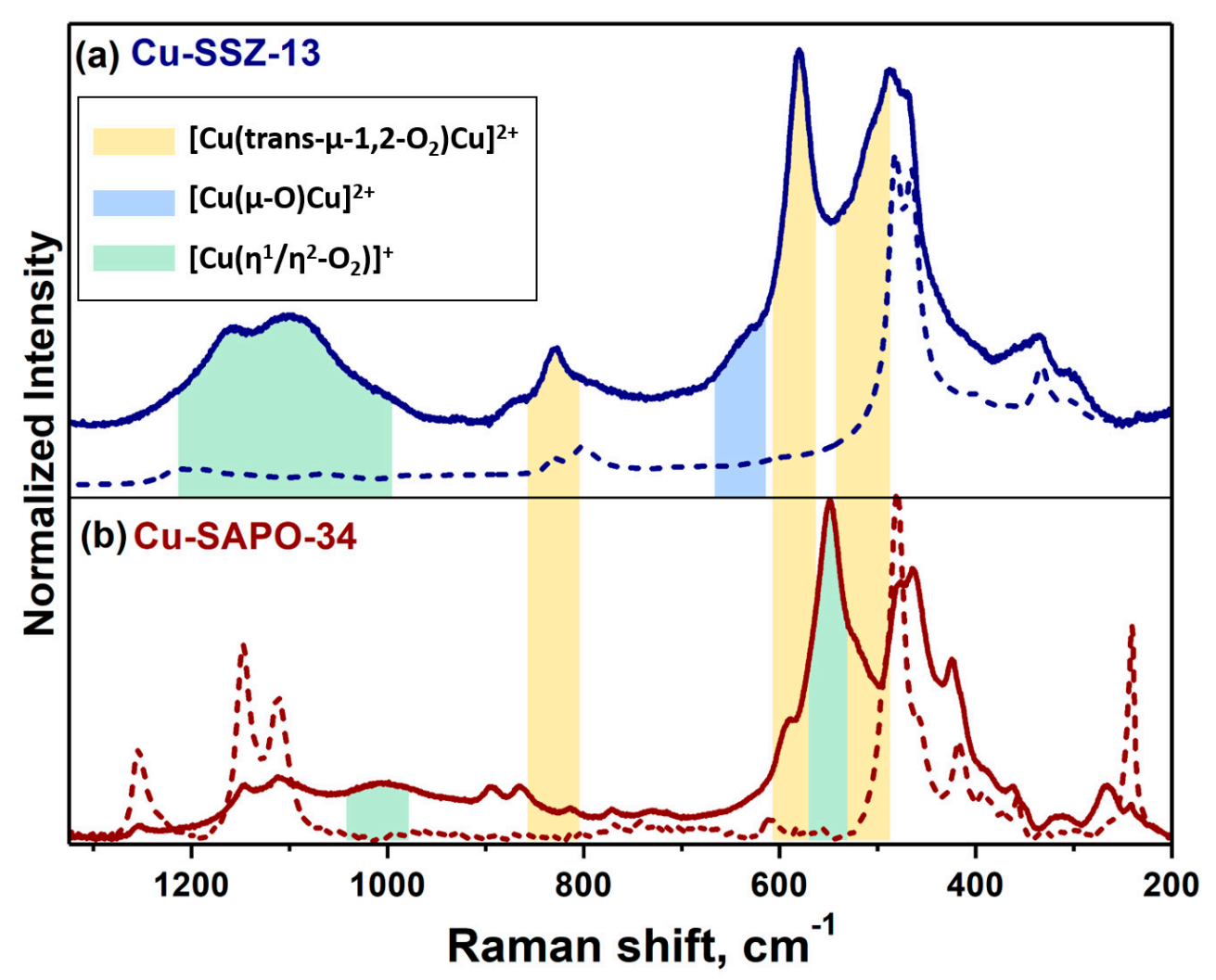

Figure 4. Raman spectra of (a) hydrated (dashed blue) and activated (solid blue) 0.50CuSSZ-13, and (b) hydrated (dashed red) and activated (solid red) 0.25CuSAPO-34. The contributions from different $\mathrm{Cu}(\mathrm{II})_{\mathrm{x}} \mathrm{O}_{\mathrm{y}}$ moieties are marked. Yellow shading: $\left[\mathrm{Cu}\left(\text { trans }-\mu-1,2-\mathrm{O}_{2}\right) \mathrm{Cu}\right]^{2+}$, blue shading: $[\mathrm{Cu}-(\mu-\mathrm{O})-\mathrm{Cu}]^{2+}$ and green shading: $\left[\mathrm{Cu}\left(\eta^{1} / \eta^{2}-\mathrm{O}_{2}\right)\right]^{+}$.

\subsubsection{IR Spectroscopy Measurements of Adsorbed CO}

By dosing $\mathrm{CO}$ on the $\mathrm{Cu}$-samples, it is possible to selectively follow the interaction of $\mathrm{CO}$ with distinct $\mathrm{Cu}(\mathrm{I})$ sites in the sample. Importantly, by probing at $\mathrm{RT}$, the $\mathrm{CO}$ interaction with Brønsted acid sites is not detectable [35,36]. Figure 5 shows the evolution of the mono- and dicarbonyl species on $\mathrm{Cu}$. Already at small doses of $\mathrm{CO}$, there is a band evolving at $2153 \mathrm{~cm}^{-1}$. This band is due to the vibration of monocarbonyl adducts $(\mathrm{Cu}(\mathrm{I})-\mathrm{CO})$ [35-37]. Since the spectra have been normalized to the framework vibration overtone mode $\left(1868 \mathrm{~cm}^{-1}\right.$ (SSZ-13) and $1853 \mathrm{~cm}^{-1}$ (SAPO-34)), weighted on the $\mathrm{Cu}$-content and background subtracted, the intensities of the bands can be directly compared for the samples with different Cu-loading. Interestingly, it can be observed that the 0.08CuSAPO-34 has a higher intensity of the band at $2153 \mathrm{~cm}^{-1}$, which could be caused by a higher fraction of $\mathrm{Cu}(\mathrm{I})$ sites that are accessible by CO. It may also be the case that some of the Cu-sites in the high-loaded SAPO-34 and/or SSZ-13 samples are more resistant to self-reduction and therefore remain as $\mathrm{Cu}$ (II) [19]. 
As the amount of CO increases, the bands at $2176 \mathrm{~cm}^{-1}$ and $2148 \mathrm{~cm}^{-1}$ develop. These bands are assigned to the symmetric and antisymmetric stretching vibration of dicarbonyl adducts $\left(\mathrm{Cu}(\mathrm{I})(\mathrm{CO})_{2}\right)$ [35-37]. It is clear that these species are more easily formed in $0.50 \mathrm{CuSSZ}-13$, as seen from the higher intensity increase of these bands. The larger amount of dicarbonyl adducts indicates that 0.50CuSSZ-13 has more freely coordinated $\mathrm{Cu}(\mathrm{I})$ species, where the $\mathrm{Cu}$ has only two or three oxygen framework neighbours. These findings support what is already observed from Raman spectroscopy.

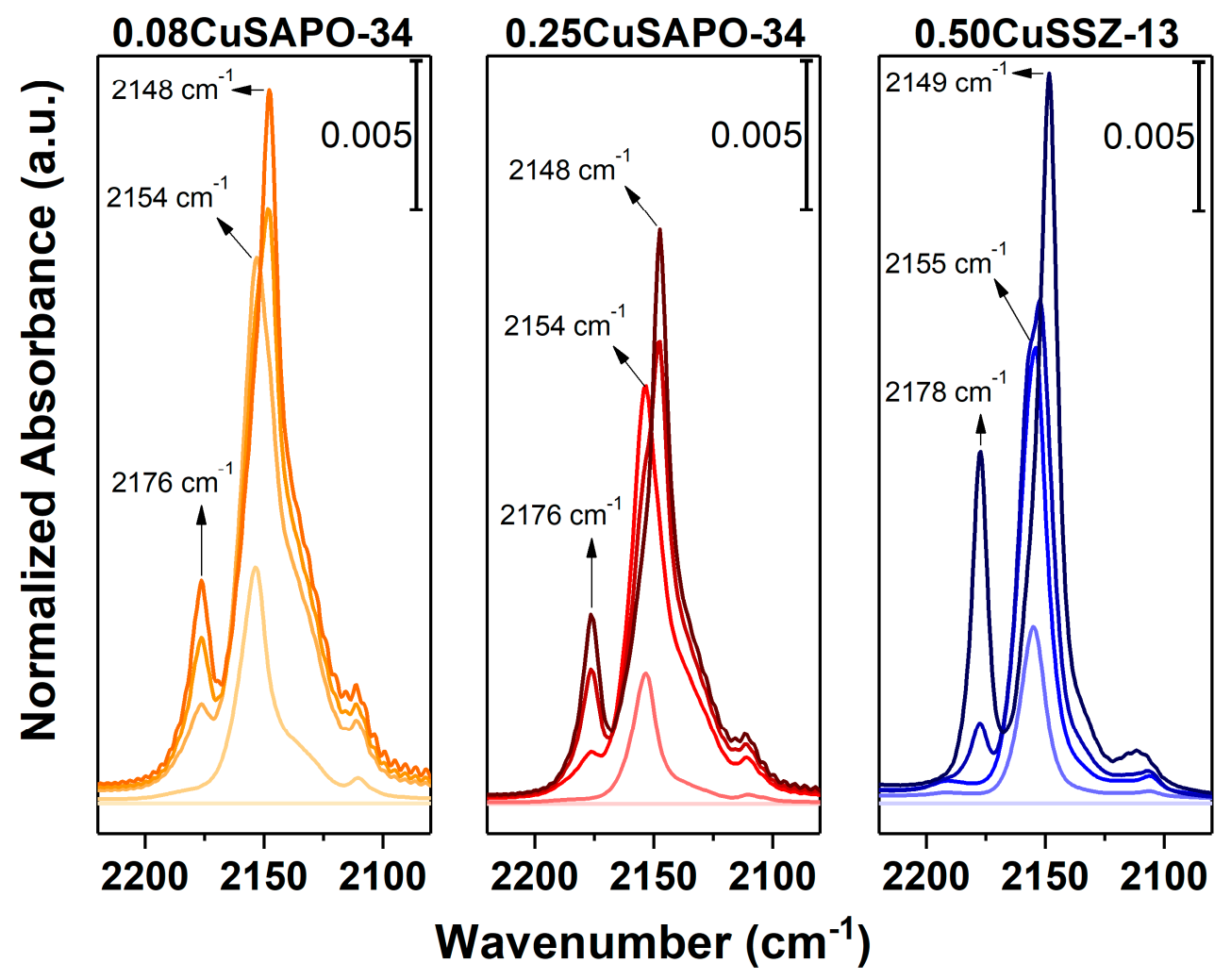

Figure 5. FT-IR spectra of adsorbed CO at RT on 0.08CuSAPO-34 (orange), 0.25CuSAPO-34 (red) and 0.50CuSSZ-13 (blue). The CO pressure was increased from $20 \mu$ bar to 20 mbar. The materials were activated for $1 \mathrm{~h}$ at $150{ }^{\circ} \mathrm{C}, 300^{\circ} \mathrm{C}$ and $450{ }^{\circ} \mathrm{C}$. The spectra are background subtracted and normalized to the framework overtones as well as to the $\mathrm{Cu}$ content $(\mu \mathrm{mol} / \mathrm{g})$.

\subsubsection{IR Spectroscopy Measurements During Heating in $\mathrm{O}_{2}$}

Pappas et al. observed evidence that $[\mathrm{Cu}(\mathrm{II}) \mathrm{OH}]^{+}$sites exists in SSZ-13, and that they act as precursors to form the active sites for the DMTM conversion [14]. When heating Cu-SSZ-13 in an $\mathrm{O}_{2}$-atmosphere while collecting IR spectra, a band at $3650 \mathrm{~cm}^{-1}$ is clearly observed, and the intensity of this band decreases with the increasing temperature. This band has previously been assigned to be the fingerprint for $\mathrm{Z}[\mathrm{Cu}(\mathrm{II}) \mathrm{OH}]$ vibration $[36,38,39]$, supporting the existence of these species and suggesting that they are likely to be precursors for other species. We therefore chose to perform the same treatment on 0.25CuSAPO-34, to see if these species exist in Cu-SAPO-34. However, as can be observed in Figure 6, it is clear that no such band exists in this sample. The only features that can be observed in the spectra are two bands at 3622 and $3594 \mathrm{~cm}^{-1}$, which are related to the $v(\mathrm{O}-\mathrm{H})$ mode of Brønsted acid sites [38,40,41]. 


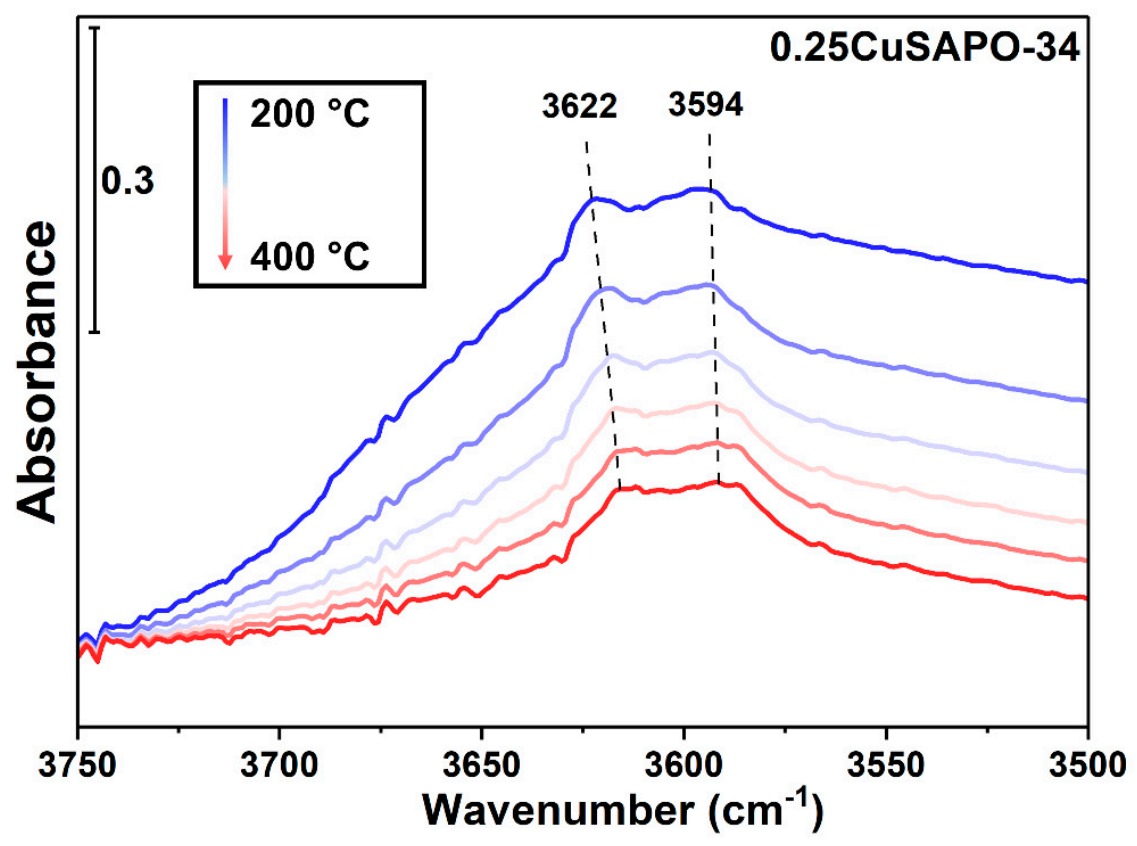

Figure 6. Spectra of $\mathrm{O}_{2}$-activated $0.25 \mathrm{CuSAPO}-34$. The temperature increases gradually from $200{ }^{\circ} \mathrm{C}$ (blue) to $400{ }^{\circ} \mathrm{C}$ (red). The dashed lines represent two peaks related to the Brønsted acid sites of the material. No band is observed at $3650 \mathrm{~cm}^{-1}$ (fingerprint region of $\mathrm{Z}[\mathrm{Cu}(\mathrm{II}) \mathrm{OH}]$ vibrations).

\subsubsection{In Situ X-ray Absorption Spectroscopy}

To investigate the oxidation state and average coordination of the $\mathrm{Cu}$ species, in situ X-ray absorption spectroscopy (XAS) measurements at the $\mathrm{Cu}$ K-edge were performed on the highest Cu-loaded SAPO-34 (0.25CuSAPO-34). The obtained spectra were compared with XAS spectra of 0.50CuSSZ-13 collected under similar conditions, see Figure 7. The spectra were collected after pre-treatment in $\mathrm{He}$ at $500{ }^{\circ} \mathrm{C}$ (dashed lines) and then after further exposure to $\mathrm{O}_{2}$ for $2-3 \mathrm{~h}$ (solid lines).

He activation of the materials results in a peak at $8983 \mathrm{eV}$, corresponding to the characteristic $1 \mathrm{~s}$ $\rightarrow 4 \mathrm{p}$ transitions of $\mathrm{Cu}(\mathrm{I})$ ions $[14,38,42-44]$. The spectrum of the He-activated material shows a highly developed $\mathrm{Cu}(\mathrm{I})$ state in $\mathrm{Cu}-\mathrm{SAPO}-34$, indicating that the $\mathrm{Cu}$ in the material undergoes "self-reduction" to a large extent $[14,38]$. The higher intensity of the peak at $8983 \mathrm{eV}$ could indicate that the degree of self-reduction of Cu-SAPO-34 is even higher than for Cu-SSZ-13, however, it could also be due to a different coordination of $\mathrm{Cu}(\mathrm{I})$-states in the two materials. Under the latter assumption, one would expect a higher fraction of linear or quasi-linear $\mathrm{Cu}(\mathrm{I})$ species in $\mathrm{Cu}-\mathrm{SAPO}-34$, while $\mathrm{Cu}(\mathrm{I})$ ions with higher coordination and/or lower $\mathrm{O}-\mathrm{Cu}-\mathrm{O}$ bond angles would be expected after He-activation in Cu-SSZ-13 [45]. Moreover, it has also previously been suggested that SAPO-34 has a higher reducibility than SSZ-13, as seen by $\mathrm{H}_{2}$-TPR experiments by Gao et al. [46]. A higher reducibility of SAPO-34 also supports the higher intensity observed for monocarbonyl adducts adsorbed on the low loaded SAPO-34 material compared to SSZ-13.

After the material is contacted with $\mathrm{O}_{2}$, a high fraction of $\mathrm{Cu}(\mathrm{I})$ is oxidized to $\mathrm{Cu}(\mathrm{II})$, as seen by the decrease of the peak at $8983 \mathrm{eV}$. The change to $\mathrm{Cu}(\mathrm{II})$ is further supported by the increase of the dipole-forbidden $1 \mathrm{~s} \rightarrow 3 \mathrm{~d}$ transition of $\mathrm{Cu}(\mathrm{II})$ ions, appearing in the pre-edge region at $8977 \mathrm{eV}$ (inset in Figure 7a) $[38,39,41,47]$. In Cu-SAPO-34, it can be observed that some of the $\mathrm{Cu}$ remains as $\mathrm{Cu}(\mathrm{I})$ after exposure to $\mathrm{O}_{2}$. This can be seen from the remaining peak at $8983 \mathrm{eV}$. It is also evident that the average coordination number of both samples is higher in the $\mathrm{O}_{2}$-activated state compared to the He-activated state, evidenced by a higher white line (WL) intensity $[14,38]$. The overall shape of the XANES and EXAFS spectra after $\mathrm{O}_{2}$-activation of the two compounds is very similar, suggesting similar $\mathrm{Cu}$ environment. Nonetheless, some difference is observed in the $\mathrm{WL}$, which appears to be slightly higher and with a somewhat different shape for Cu-SSZ-13 than for Cu-SAPO-34. This observation is 
further supported by the higher intensity of the first shell of the EXAFS spectra (Figure 7). This EXAFS feature is linked with $\mathrm{Cu}-\mathrm{O}$ single scattering (ss) paths involving framework $\left(\mathrm{O}_{\mathrm{fw}}\right)$ and possibly extra framework $\left(\mathrm{O}_{\mathrm{ef}}\right)$ oxygen atoms in the first coordination shell of $\mathrm{Cu}$ ions [14]. As evidenced from the dipole-forbidden $1 \mathrm{~s} \rightarrow 3 \mathrm{~d}$ transition in the pre-edge region, there is more $\mathrm{Cu}$ (II) present in SSZ-13 than in SAPO-34 after $\mathrm{O}_{2}$-activation. More $\mathrm{Cu}$ in a higher oxidation state is usually linked with a higher coordination number to $\mathrm{O}$ atomic neighbours in the first shell, which consequently explains the observed difference in the shape and intensity of the XANES WL as well as the higher first shell intensity of the FT-EXAFS spectra for SSZ-13 and SAPO-34 recorded after $\mathrm{O}_{2}$-activation.

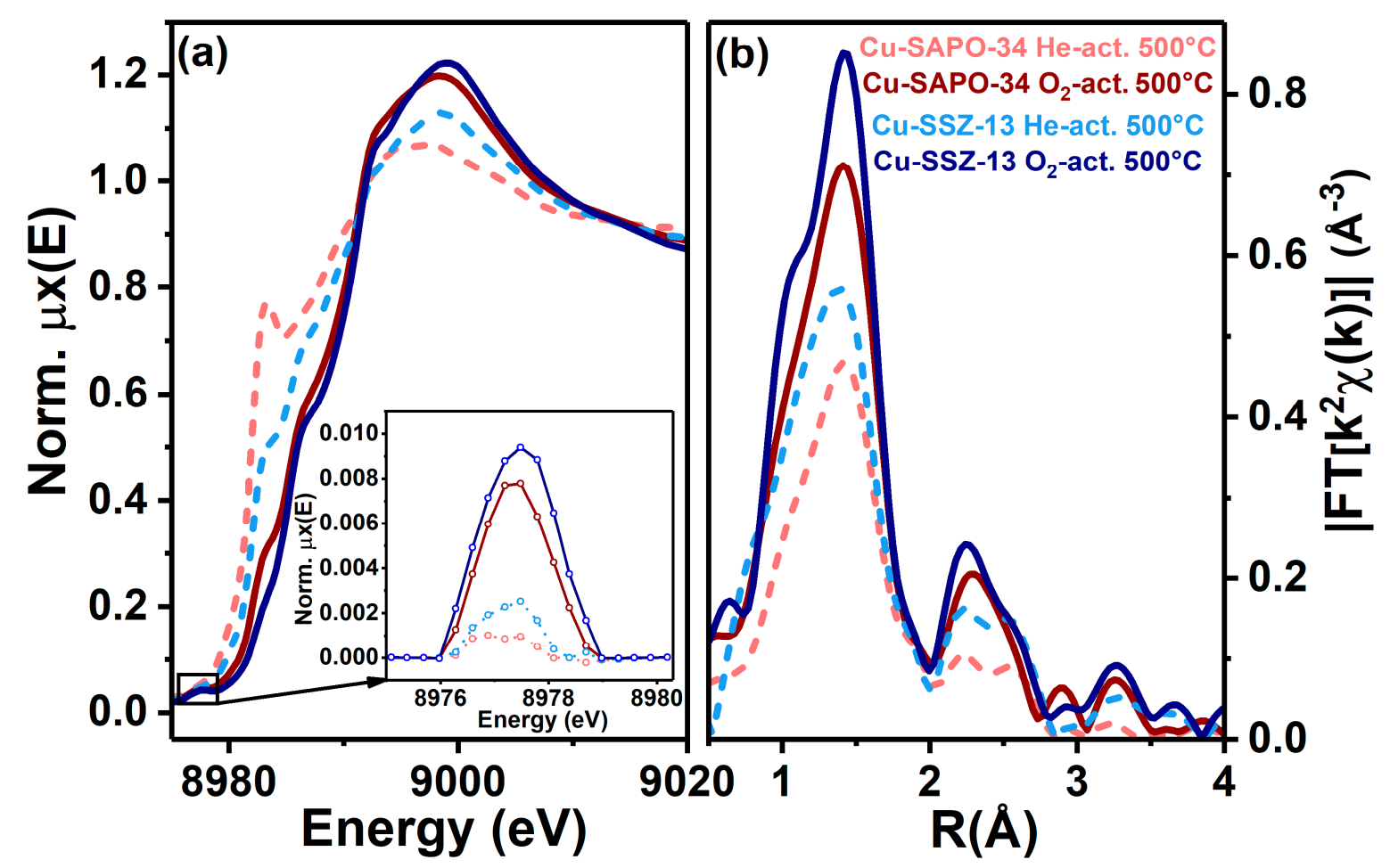

Figure 7. XANES (a) and FT-EXAFS (b) spectra of 0.25CuSAPO-34 (red) and 0.50CuSSZ-13 (blue) after He-activation at $500{ }^{\circ} \mathrm{C}$ (light coloured, dotted lines) and after consecutive $\mathrm{O}_{2}$-activation for $1 \mathrm{~h}$ (dark coloured, solid lines). The inset in (a) is an enhancement of the dipole-forbidden $1 \mathrm{~s} \rightarrow 3 \mathrm{~d}$ transition in the pre-edge region.

\subsection{Comparing the $\mathrm{CH}_{4}$ Consumption}

Based on the Raman and IR spectroscopies, we suggest that more highly coordinated Cu-species are hosted in SAPO-34. If this is combined with the knowledge that SAPO-34 has a more restricted placement of $\mathrm{Si}$ in the framework, which leads to fewer acid sites in close proximity, it can be suggested that more of the $\mathrm{Cu}$ in SAPO-34 exists as monomeric isolated $\mathrm{Cu}$-sites, compared to SSZ-13. Recently, van Bokhoven and coworkers performed $\mathrm{CH}_{4}$-TPR on various zeolites, as well as monitored, with XANES, the $\mathrm{Cu}(\mathrm{I})$ formation in MOR zeolites with different $\mathrm{Cu}$-loadings and were able to show that more isolated $\mathrm{Cu}$-sites need a higher temperature to be reduced [20,21]. Based on these observations, we similarly performed $\mathrm{CH}_{4}$-TPR on the SAPO-34 and SSZ-13 samples investigated in this work. The consumption of $\mathrm{CH}_{4}$ is shown in Figure 8, while the total oxidation to $\mathrm{CO}_{2}$ is reported in Figure S4. It is clear from the results that the $\mathrm{CH}_{4}$-consumption starts at a substantially lower temperature in 0.50CuSSZ-13 (ca. $200{ }^{\circ} \mathrm{C}$ ) than in 0.08CuSAPO-34 and 0.25CuSAPO-34 (ca. 280 and $300^{\circ} \mathrm{C}$, respectively). 


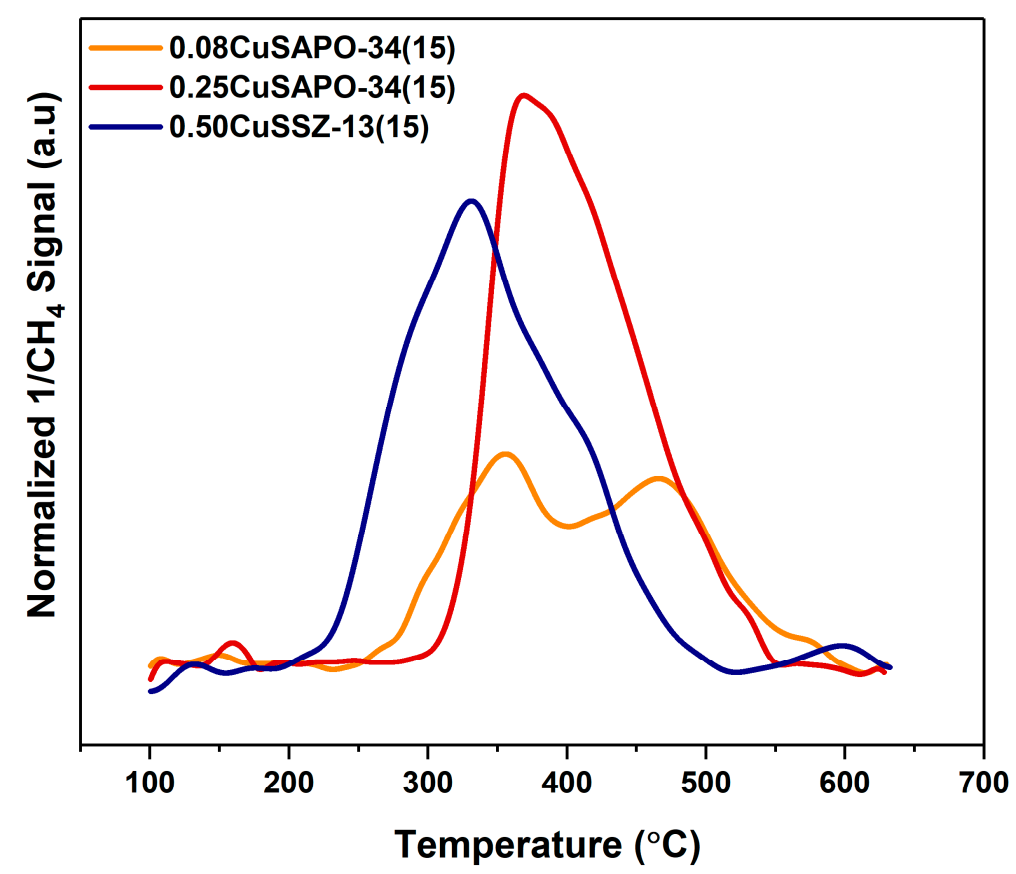

Figure 8. Inversed $\mathrm{CH}_{4}$ consumption of 0.50CuSSZ-13 (blue), 0.08CuSAPO-34 (orange) and 0.25CuSAPO-34 (red) measured by an online MS during flow of $\mathrm{CH}_{4}$ while heating from 100 to $650{ }^{\circ} \mathrm{C}$ (ramp: $5^{\circ} \mathrm{C} / \mathrm{min}$ ). The materials were activated at $500{ }^{\circ} \mathrm{C}$ in $\mathrm{O}_{2}$ for $8 \mathrm{~h}$ prior to the $\mathrm{CH}_{4}$-TPR experiment. The graphs have been normalized to the sample weight.

\subsection{Optimization of the Test Parameters}

Based on the differences in $\mathrm{CH}_{4}$-oxidation temperature observed in the TPR profiles, we changed the test parameters by increasing the $\mathrm{CH}_{4}$-loading temperature from 200 to $300{ }^{\circ} \mathrm{C}$ for the two SAPO-34 materials (Test \#2 reported in Table 1). The performances thus obtained are plotted in Figure 9 together with the previous results for clarity. Interestingly, after increasing the $\mathrm{CH}_{4}$-loading temperature, we observe a tenfold increase in the $\mathrm{CH}_{3} \mathrm{OH}$-yield over 0.08CuSAPO-34 and 0.25CuSAPO-34, while the $\mathrm{CH}_{3} \mathrm{OH}$-yield from 0.50CuSSZ-13 decreases significantly, indicating a loss in selectivity, as also suggested from $\mathrm{CO}_{2}$ production observed with $\mathrm{CH}_{4}$-TPR experiments (Figure S4). When normalizing the yield to the $\mathrm{Cu}$-content, $0.08 \mathrm{CuSAPO}-34$ reaches even a higher productivity than that observed for 0.50CuSSZ-13 at a $200{ }^{\circ} \mathrm{C} \mathrm{CH}_{4}$-loading temperature. The parent materials, H-SAPO-34 and H-SSZ-13, were also tested with a $300^{\circ} \mathrm{CCH}_{4}$-loading temperature. Both parent samples had a productivity of less than $2 \mu \mathrm{mol} / \mathrm{g}$, proving that the productivity of the materials derive from the $\mathrm{O}_{2}$-activated $\mathrm{Cu}$-species. 


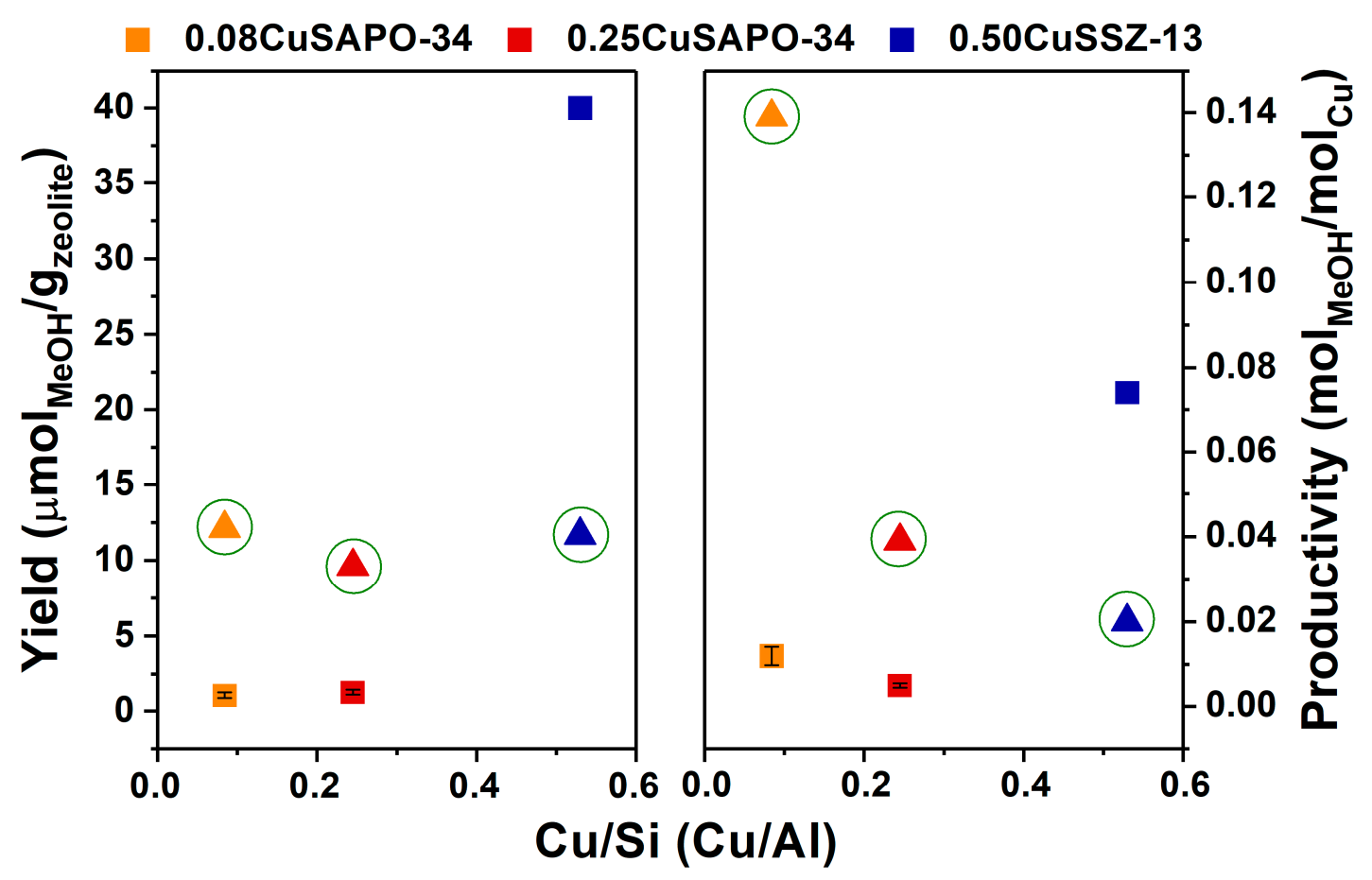

Figure 9. Comparison of the standard test conditions (Test \#1-represented by squares) to the high temperature $\mathrm{CH}_{4}$-loading test conditions (Test \#2-represented by green circled triangles). The panel on the left shows $\mathrm{CH}_{3} \mathrm{OH}$ yield per gram of zeolite. The panel on the right gives the $\mathrm{CH}_{3} \mathrm{OH}$ yield normalized to the $\mathrm{Cu}$ content $\left(\mathrm{mol}_{\mathrm{CH} 3 \mathrm{OH}} / \mathrm{mol}_{\mathrm{Cu}}\right)$. Colours: $0.08 \mathrm{CuSAPO}-34$ (orange), $0.25 \mathrm{CuSAPO}-34$ (red) and 0.50CuSSZ-13 (blue). The estimated error from DMTM conversion over the Cu-SAPO-34 materials in Test \#1 is shown as black error bars inside the squares.

\section{Materials and Methods}

\subsection{Material Synthesis}

The synthesis and ion exchange procedure for the SSZ-13 zeolite $(\mathrm{Si} / \mathrm{Al}=15)$ is reported in a previous article [14], while the synthesis procedures performed on $(\mathrm{Cu}-) \mathrm{SAPO}-34((\mathrm{Al}+\mathrm{P}) / \mathrm{Si}=15)$ is described below.

The parent SAPO-34 was synthesized according the synthesis route reported by Mertens [48]. The final gel had a molar ratio of $0.3 \mathrm{SiO}_{2} / 1 \mathrm{Al}_{2} \mathrm{O}_{3} / 1 \mathrm{P}_{2} \mathrm{O}_{5} / 1$ TEAOH/35 $\mathrm{H}_{2} \mathrm{O}$. First, orthophosphoric acid, ( $85 \%$, Merck), tetraethyl ammonium hydroxide (TEAOH, $35 \%$, Sigma-Aldrich) and deionised water were mixed. The mixture was then heated to $30{ }^{\circ} \mathrm{C}$, after which silica (ludox-AS- $40,40 \% \mathrm{SiO}_{2}$, DuPont) and alumina (Pural SB, $76 \% \mathrm{Al}_{2} \mathrm{O}_{3}, \mathrm{SASOL}$ ) were added under continuous stirring, before aging at $30^{\circ} \mathrm{C}$ for $2 \mathrm{~h}$. Thereafter, the aged gel was transferred into Teflon lined autoclaves, and heated to $165^{\circ} \mathrm{C}$, and kept there for $72 \mathrm{~h}$ with rotation. The heating rate was $5^{\circ} \mathrm{C} / \mathrm{h}$. Last, the reaction was stopped by quenching, and the obtained powder was washed well with deionised water before drying over night at $95^{\circ} \mathrm{C}$. The proton form of SAPO-34 was obtained by calcining the material in static air at $600{ }^{\circ} \mathrm{C}$ for $15 \mathrm{~h}$. The heating rate was $2{ }^{\circ} \mathrm{C} / \mathrm{min}$, starting from room temperature (RT). Liquid ion exchange (LIE) was performed to incorporate $\mathrm{Cu}$. For the low loaded material $(\mathrm{Cu} / \mathrm{Si}=0.08)$, a $0.02 \mathrm{M}$ $\mathrm{CuAc}_{2}$-solution was prepared and stirred with the material $(60 \mathrm{~mL}$ solution/g of zeolite) at RT for $24 \mathrm{~h}$. The $\mathrm{pH}$ of the solution was kept in the 5.5-6 range. After stirring, the material was washed and centrifuged three times. The high loaded material was prepared in the same way, but the process was repeated three times, with a calcining step between each round $\left(600{ }^{\circ} \mathrm{C}, 15 \mathrm{~h}, 2^{\circ} \mathrm{C} / \mathrm{min}\right)$. The $\mathrm{CuAc}_{2}$ solution used in the first round was $0.02 \mathrm{M}$. For the second and third round, a $\mathrm{CuAc}_{2}$-solution resulting in a $\mathrm{Cu} / \mathrm{Si}$ ratio of 0.5 was used $(0.008 \mathrm{M})$. 


\subsection{Characterization}

Powder X-ray diffraction patterns of the materials, before and after $\mathrm{Cu}$-incorporation were obtained on a Bruker D8 Discover Diffractometer with a $\mathrm{Cu} \mathrm{K} \alpha$ radiation $(\lambda=1.5406 \AA)$.

Thermogravimetric analysis was used to find the dry weight of the $\mathrm{Cu}$-exchanged materials. For all measurements, a small platinum crucible, filled with a small amount of sample (around $25 \mathrm{mg}$ ), was placed inside a Stanton Redcroft furnace. The samples were heated to $300{ }^{\circ} \mathrm{C}$ with a heating rate of $2{ }^{\circ} \mathrm{C} / \mathrm{min}$. The material was kept at $300^{\circ} \mathrm{C}$ for $30 \mathrm{~min}$ and then slowly cooled to RT.

Specific surface area and pore volume were measured by $\mathrm{N}_{2}$-adsorption experiments, performed at $-196{ }^{\circ} \mathrm{C}$ on approximately $40 \mathrm{mg}$ of sample, by estimating the BET isotherm. The data were collected on a BelSorp MINI instrument. The materials were first pre-treated in vacuum $\left(1 \mathrm{~h}\right.$ at $80^{\circ} \mathrm{C}$, and $2 \mathrm{~h}$ at $300^{\circ} \mathrm{C}$ ). The $\mathrm{p} / \mathrm{p}_{0}$ range used for the BET surface area was $0.0-0.1$.

Scanning electron microscopy (SEM) was used to investigate the crystal morphology. The images were collected on a Hitachi SU8230 in deceleration mode. Energy dispersive X-ray (EDX) was used to obtain the elemental composition of the materials (e.g., $\mathrm{Cu} / \mathrm{Si}$ and $(\mathrm{Al}+\mathrm{P}) / \mathrm{Si})$. A small amount of powder was pressed ( 5 tons) into a self-supporting wafer, and placed on a carbon tape on top of a carbon holder, prior to the EDX-measurements.

CO-adsorption at RT was characterized by IR spectroscopy on 0.08CuSAPO-34, 0.25CuSAPO-34 and 0.50CuSSZ-13, in order to investigate the interaction of $\mathrm{CO}$ adsorbed on the $\mathrm{Cu}$-sites. Each material was pressed into a self-supporting wafer $\left(11.3 \mathrm{mg} / \mathrm{cm}^{2}\right)$ and placed inside a gold envelope. The material was pre-treated in a vacuum for $1 \mathrm{~h}$ at $150{ }^{\circ} \mathrm{C}, 1 \mathrm{~h}$ at $300^{\circ} \mathrm{C}$ and $1 \mathrm{~h}$ at $450{ }^{\circ} \mathrm{C}$. After cooling, small amounts of $\mathrm{CO}$ were dosed repeatedly into the cell at RT, until reaching about a $\mathrm{CO}$ equilibrium pressure of 20 mbar. A spectrum was recorded after each dosing.

Raman spectroscopy measurements were used to investigate $\mathrm{Cu}-\mathrm{O}$ and $\mathrm{O}-\mathrm{O}$ vibrations in the $\mathrm{Cu}$ exchanged SAPO-34 and SSZ-13 materials. The samples were investigated at RT, both as-synthesized (hydrated), as well as in sealed capillaries after activation in static air atmosphere. For measuring the activated samples, boron-silicate glass capillaries ( $0.5 \mathrm{~mm}$ diameter and $0.01 \mathrm{~mm}$ wall thickness) containing the studied materials were heated to $550{ }^{\circ} \mathrm{C}$, with a $3^{\circ} \mathrm{C} / \mathrm{min}$ ramp and kept overnight $(14$ $\mathrm{h})$ at the same temperature. The capillaries were then sealed with a flame gun while hot, and then slowly cooled to RT. The spectra were collected with a blue laser $(488 \mathrm{~nm})$ and recorded with a Horiba LabRamanHR microscope, equipped with a Coherent Sapphire laser. The signal was dispersed over a 1800 lines/mm grating on a thermoelectrically cooled CCD detector. The excitation beam was focused on the sample with a 50x objective lens.

In situ X-ray absorption spectroscopy (XAS) experiments were performed at the BM23 beamline of the European Synchrotron Radiation Facility (ESRF) in Grenoble. The measurements were performed in a Microtomo reactor cell designed by the ESRF Sample Environment group [49], integrated in a dedicated gas flow setup. Before starting the measurements, the samples were transformed into self-supporting pellets (ca. $85 \mathrm{mg} / \mathrm{cm}^{2}$ ) This leads to edge jumps in the $0.4-0.9$ region and total absorption $\mu \mathrm{x}=2.5$. The in situ procedure applied was as described previously by Pappas et al. [14], where the samples were heated in He from RT to $500{ }^{\circ} \mathrm{C}$ with a heating ramp of $5{ }^{\circ} \mathrm{C} / \mathrm{min}$ and a flow rate of $100 \mathrm{~mL} / \mathrm{min}$. After activation, an $\mathrm{O}_{2}$ flow $(100 \mathrm{~mL} / \mathrm{min})$ was introduced for $180 \mathrm{~min}$. With the use of a liquid $\mathrm{N}_{2}$-cooled flat $\mathrm{Si}(111)$ double-crystal monochromator, the $\mathrm{Cu}$ K-edge spectra were collected in transmission mode. Ionization chambers filled with $\mathrm{Ar}$ and He were used to detect the incident $\left(\mathrm{I}_{0}\right)$ and transmitted $\left(\mathrm{I}_{1,2}\right)$ X-ray intensities. The third ionization chamber $\left(\mathrm{I}_{2}\right)$ was used to collect the XANES spectrum of a Cu metal foil simultaneously with the samples. [50] After the samples had been stabilised at constant temperature in static conditions, high quality EXAFS scans were collected. These were acquired in the $8800-9955 \mathrm{eV}$ range with an energy step of $5 \mathrm{eV}$ in the pre-edge region, $0.3 \mathrm{eV}$ in the XANES region and a constant $\mathrm{k}$ step of $\Delta \mathrm{k}=0.035 \AA^{-1}$ in the EXAFS region. With an integration time of $1 \mathrm{~s} /$ point, the resulting acquisition of the whole spectrum was $17 \mathrm{~min} / \mathrm{scan}$. For analysis, all XAS spectra were normalized to unity edge jump, and thereafter aligned in energy by applying the Athena software from the Demeter package [51]. To characterize the static states, three/four consecutive XAS 
scans were collected, and after checking for signal reproducibility, the scans were averaged to the corresponding $\mu \mathrm{x}(\mathrm{E})$ curves. The $\chi(\mathrm{k})$ EXAFS functions were extracted using the Athena program, and by transforming the $\mathrm{k}^{2} \chi(\mathrm{k})$ functions in the range of 2.4-13.0 $\AA^{-1}$, the Fourier-Transform (FT) EXAFS spectra were obtained.

$\mathrm{CH}_{4}$-TPR experiments were performed using a U-shaped fixed bed reactor. The effluent was monitored with an online Pfeiffer MS. About $100 \mathrm{mg}$ of material was used for the measurements. The flows of $\mathrm{CH}_{4}(100 \%)$, He $(100 \%)$ and $\mathrm{O}_{2}(100 \%)$ were controlled by needle valve/rotameter controllers and fed stepwise to the reactor with the use of stop- and 4-way valves. The total gas flow was always $15 \mathrm{~mL} / \mathrm{min}$. The reaction protocol consisted of heating the material at $500{ }^{\circ} \mathrm{C}$ in $\mathrm{O}_{2}(8 \mathrm{~h})$, before the reactor was cooled to $100^{\circ} \mathrm{C}$, and flushed with $\mathrm{He}$ for $1 \mathrm{~h}$. Then $\mathrm{CH}_{4}$ was introduced, while the temperature was ramped $\left(5^{\circ} \mathrm{C} / \mathrm{min}\right)$ to $650^{\circ} \mathrm{C}$.

\subsection{Performance Tests}

The direct conversion of methane to methanol over the materials was tested with a purpose-designed setup. Before exposing the material to the test conditions, the samples were crushed and sieved with a sieve fraction of $250-425 \mu \mathrm{m}$. $100 \mathrm{mg}$ of the sample was transferred to a straight quartz tube (i.d. $=6 \mathrm{~mm}$ ) containing a porous plug. The reactor was connected to the gas lines inside a tubular oven. The reaction temperature was monitored by inserting a thermocouple placed inside a quartz sheath at the top of the reactor bed. The flow of $\mathrm{CH}_{4}(100 \%), \mathrm{He}(100 \%), \mathrm{O}_{2}(100 \%)$ and a $\mathrm{Ne} / \mathrm{He}$ mixture $(10 \% \mathrm{Ne}$ in $\mathrm{He})$ was controlled by MFCs and fed stepwise to the reactor with the use of stop- and 4-way valves. To obtain approximately $10 \%$ water in the $\mathrm{Ne} / \mathrm{He}$-stream passing through the reactor, the mixture was bubbled through a saturator immersed in an oil bath heated to $45^{\circ} \mathrm{C}$ (water vapour pressure $\approx 9.6 \mathrm{kPa}$ ).

The standard reaction procedure (test \#1) consisted of dehydrating the material at $150^{\circ} \mathrm{C}$ in $\mathrm{He}$ $(15 \mathrm{~mL} / \mathrm{min})$, before a flow of pure $\mathrm{O}_{2}$ was introduced, and the temperature increased to $500{ }^{\circ} \mathrm{C}$ with a heating rate of $5{ }^{\circ} \mathrm{C} / \mathrm{min}$. The material was kept at $500{ }^{\circ} \mathrm{C}$ in $\mathrm{O}_{2}(15 \mathrm{~mL} / \mathrm{min})$ for $8 \mathrm{~h}$. Then, the temperature was decreased $\left(5^{\circ} \mathrm{C} / \mathrm{min}\right)$ to $200{ }^{\circ} \mathrm{C}$, and $\mathrm{CH}_{4}(15 \mathrm{~mL} / \mathrm{min})$ was purged for $3 \mathrm{~h}$. Finally, a $10 \% \mathrm{H}_{2} \mathrm{O}$-saturated $\mathrm{Ne} / \mathrm{He}$ stream $(14.9 \mathrm{~mL} / \mathrm{min})$ was introduced to extract the selectively oxidized products out of the pores. The detected products were methanol, dimethyl ether (counted as two methanol molecules) and some $\mathrm{CO}_{\mathrm{x}}$ species. The reaction conditions are summarized in Table 1 below.

Table 1. Test conditions applied for the DMTM conversion.

\begin{tabular}{ccccc}
\hline & $\begin{array}{c}\text { He Activation } \\
\left({ }^{\circ} \mathbf{C}\right) \\
\text { (Time(min)) }\end{array}$ & $\begin{array}{c}\mathrm{O}_{2} \text { Activation } \\
\left({ }^{\circ} \mathbf{C}\right) \\
(\text { Time(min)) }\end{array}$ & $\begin{array}{c}\mathrm{CH}_{4} \text { Loading } \\
\left({ }^{\circ} \mathbf{C}\right) \\
\text { (Time(min)) }\end{array}$ & $\begin{array}{c}\mathbf{H}_{2} \mathbf{O}-\text { Assisted } \\
\mathbf{C H}_{3} \text { OH ext. } \\
\left({ }^{\circ} \mathbf{C}\right)\end{array}$ \\
\hline Test \#1 & 150 & 500 & 200 & 200 \\
Test \#2 & $(\sim 120)$ & $(480)$ & $(180)$ & $(\sim 120)$ \\
& 150 & 500 & 300 & 200 \\
& $(\sim 120)$ & $(480)$ & $(180)$ & $(\sim 120)$ \\
\hline
\end{tabular}

The effluent from Test \#1 (Table 1) were analysed with a Hewlett Packard 6890/6972 GC-MS. This was equipped with a Supel-Q PLOT capillary column and the carrier gas was He. Analysis was conducted isothermally at $125^{\circ} \mathrm{C}$ and the analysis time was $3.5 \mathrm{~min}$. Samples were injected every $4 \mathrm{~min}$ and repeated 30 times during extraction. Combined, the chromatography and mass selective detector allow separation and accurate analysis of all relevant components in the effluent. For Test \#2 (Table 1), an online Pfeiffer MS was used to analyse the effluent. 


\section{Conclusions}

To summarize, it has been observed that there are large differences in the $\mathrm{Cu}$ speciation of the two CHA topology materials - SAPO-34 and SSZ-13 - as observed from XAS, Raman and IR spectroscopies. These differences are due to several important factors. The polarity of the framework, induced by the different framework components, is likely to have a large impact on the location and coordination of the $\mathrm{Cu}$-species. In addition, the multiple Si substitution mechanisms in SAPO-34 affect the amount and distribution of ion exchange sites, leading to fewer Cu-sites in close proximity in SAPO-34 than in SSZ-13. With $\mathrm{CH}_{4}$-TPR experiments, we supported the hypothesis that SAPO-34 has more isolated $\mathrm{Cu}$-sites, by observing that a higher temperature was needed to oxidize $\mathrm{CH}_{4}$. By changing the $\mathrm{CH}_{4}$-loading temperature from 200 to $300^{\circ} \mathrm{C}$ we observed more than a tenfold increase in methanol yield from 1 to $12 \mu \mathrm{mol} / \mathrm{g}$ for $0.08 \mathrm{CuSAPO}-34$. These results show that the framework polarity and acid site proximity play an important role for the $\mathrm{Cu}$-speciation. Furthermore, it is evident that the redox properties of the materials are strongly influenced by the $\mathrm{Cu}$-speciation. These results indicate that $\mathrm{CH}_{4}$-TPR can function as a possible descriptor for the reducibility of the $\mathrm{Cu}$-sites in zeolites, and we suggest that $\mathrm{CH}_{4}$-TPR will be an important tool in future work for tuning metal-loaded zeolites under different reaction conditions and finding the best suited process for direct conversion of methane to methanol.

Supplementary Materials: The following are available online at http://www.mdpi.com/2073-4344/10/2/191/s1, Figure S1: SEM images, Figure S2: PXRD patterns of SAPO-34, Figure S3: PXRD patterns of Cu-SAPO-34, Figure S4: $\mathrm{CO}_{2}$ production from $\mathrm{CH}_{4}$-TPR. Table S1: physicochemical characterization, Table S2: Raman spectroscopy assignments.

Author Contributions: Testing, Cu-exchange, standard characterization, K.K., D.K.P., M.D.; spectroscopy measurements and writing of original draft, K.K.; Collection of XAS data, K.A.L.; Analysis of XAS data, E.B.; Data analysis and interpretation, K.K., C.B., S.B., G.B., B.A., M.S., D.K.P., M.D., E.B.; Review and editing, M.S., E.B., K.A.L., S.B., B.A., S.S.; Supervision and funding acquisition, P.B., U.O., S.S. All authors have read and agreed to the published version of the manuscript.

Funding: This publication forms a part of the iCSI (industrial Catalysis Science and Innovation) Centre for Research-based Innovation, which receives financial support from the Research Council of Norway under contract no. 237922. A.L. and C.B. acknowledges the Research Council of Norway for financial support (FRINATEK Toppforsk Grant no. 250795 CONFINE).

Acknowledgments: Anna Lind, SINTEF, is acknowledged for preparing the as-synthesized SAPO-34 material. Andrea Lazzarini (A.L.) is acknowledged for support in the collection of IR spectra.

Conflicts of Interest: The authors declare no conflict of interest.

\section{References}

1. Schwach, P.; Pan, X.; Bao, X. Direct Conversion of Methane to Value-Added Chemicals over Heterogeneous Catalysts: Challenges and Prospects. Chem. Rev. 2017, 117, 8497-8520. [CrossRef] [PubMed]

2. Park, M.B.; Park, E.D.; Ahn, W.-S. Recent Progress in Direct Conversion of Methane to Methanol Over Copper-Exchanged Zeolites. Front. Chem. 2019, 7, 1-7. [CrossRef] [PubMed]

3. McFarland, E. Unconventional Chemistry for Unconventional Natural Gas. Science 2012, 338, 340. [CrossRef] [PubMed]

4. Zero Routine Flaring by 2030. Available online: http://www.worldbank.org/en/programs/zero-routineflaring-by-2030\#1 (accessed on 8 January 2019).

5. The Many Uses of Methanol—From Clothing to Fuel. Available online: https://www.mgc.co.jp/eng/rd/ technology/methanol.html (accessed on 31 January 2020).

6. Fleisch, T.H.; Basu, A.; Sills, R.A. Introduction and advancement of a new clean global fuel: The status of DME developments in China and beyond. J. Nat. Gas Sci. Eng. 2012, 9, 94-107. [CrossRef]

7. Semelsberger, T.A.; Borup, R.L.; Greene, H.L. Dimethyl ether (DME) as an alternative fuel. J. Power Sources 2006, 156, 497-511. [CrossRef]

8. Bjorck, C.E.; Dobson, P.D.; Pandhal, J. Biotechnological conversion of methane to methanol: Evaluation of progress and potential. Environ. Sci. 2018, 5, 1-38. [CrossRef] 
9. Sushkevich, V.L.; Palagin, D.; Ranocchiari, M.; van Bokhoven, J.A. Selective Anaerobic Oxidation of Methane Enables Direct Synthesis of Methanol. Science 2017, 356, 523-527. [CrossRef] [PubMed]

10. Alayon, E.M.; Nachtegaal, M.; Ranocchiari, M.; van Bokhoven, J.A. Catalytic conversion of methane to methanol over Cu-mordenite. Chem. Commun. 2012, 48, 404-406. [CrossRef] [PubMed]

11. Grundner, S.; Markovits, M.A.; Li, G.; Tromp, M.; Pidko, E.A.; Hensen, E.J.; Jentys, A.; Sanchez-Sanchez, M.; Lercher, J.A. Single-site trinuclear copper oxygen clusters in mordenite for selective conversion of methane to methanol. Nat. Commun. 2015, 6, 7546. [CrossRef] [PubMed]

12. Grundner, S.; Luo, W.; Sanchez-Sanchez, M.; Lercher, J.A. Synthesis of Single-Site Copper Catalysts for Methane Partial Oxidation. Chem. Commun. 2016, 52, 2553-2556. [CrossRef] [PubMed]

13. Tomkins, P.; Mansouri, A.; Bozbag, S.E.; Krumeich, F.; Park, M.B.; Alayon, E.M.; Ranocchiari, M.; van Bokhoven, J.A. Isothermal Cyclic Conversion of Methane into Methanol over Copper-Exchanged Zeolite at Low Temperature. Angew. Chem. Int. Ed. 2016, 55, 5467-5471. [CrossRef]

14. Pappas, D.K.; Borfecchia, E.; Dyballa, M.; Pankin, I.A.; Lomachenko, K.A.; Martini, A.; Signorile, M.; Teketel, S.; Arstad, B.; Berlier, G.; et al. Methane to Methanol: Structure-Activity Relationships for Cu-CHA. J. Am. Chem. Soc. 2017, 139, 14961-14975. [CrossRef]

15. Wulfers, M.J.; Teketel, S.; Ipek, B.; Lobo, R.F. Conversion of methane to methanol on copper-containing small-pore zeolites and zeotypes. Chem. Commun. 2015, 51, 4447-4450. [CrossRef] [PubMed]

16. Groothaert, M.H.; Smeets, P.J.; Sels, B.F.; Jacobs, P.A.; Schoonheydt, R.A. Selective oxidation of methane by the bis( $\mu$-oxo)dicopper core stabilized on ZSM-5 and mordenite zeolites. J. Am. Chem. Soc. 2005, 127, 1394-1395. [CrossRef] [PubMed]

17. Woertink, J.S.; Smeets, P.J.; Groothaert, M.H.; Vance, M.A.; Sels, B.F.; Schoonheydt, R.A.; Solomon, E.I. A $\left[\mathrm{Cu}_{2} \mathrm{O}\right]^{2+}$ Core in Cu-ZSM-5, the Active Site in the Oxidation of Methane to Methanol. Proc. Natl. Acad. Sci. USA 2009, 106, 18908-18913. [CrossRef] [PubMed]

18. Dyballa, M.; Pappas, D.K.; Kvande, K.; Borfecchia, E.; Arstad, B.; Beato, P.; Olsbye, U.; Svelle, S. On How Copper Mordenite Properties Govern the Framework Stability and Activity in the Methane-to-Methanol Conversion. ACS Catal. 2019, 9, 365-375. [CrossRef]

19. Pappas, D.K.; Martini, A.; Dyballa, M.; Kvande, K.; Teketel, S.; Lomachenko, K.A.; Baran, R.; Glatzel, P.; Arstad, B.; Berlier, G.; et al. The Nuclearity of the Active Site for Methane to Methanol Conversion in Cu-Mordenite: A Quantitative Assessment. J. Am. Chem. Soc. 2018, 140, 15270-15278. [CrossRef]

20. Sushkevich, V.L.; Smirnov, A.V.; van Bokhoven, J.A. Autoreduction of Copper in Zeolites: Role of Topology, Si/Al Ratio, and Copper Loading. J. Phys. Chem. C 2019, 123, 9926-9934. [CrossRef]

21. Sushkevich, V.L.; van Bokhoven, J.A. Methane-to-Methanol: Activity Descriptors in Copper-Exchanged Zeolites for the Rational Design of Materials. ACS Catal. 2019, 9, 6293-6304. [CrossRef]

22. Ravi, M.; Sushkevich, V.L.; Knorpp, A.J.; Newton, M.A.; Palagin, D.; Pinar, A.B.; Ranocchiari, M.; van Bokhoven, J.A. Misconceptions and challenges in methane-to-methanol over transition-metal-exchanged zeolites. Nat. Catal. 2019, 2, 485-494. [CrossRef]

23. Lomachenko, K.A.; Martini, A.; Pappas, D.K.; Negri, C.; Dyballa, M.; Berlier, G.; Bordiga, S.; Lamberti, C.; Olsbye, U.; Svelle, S.; et al. The impact of reaction conditions and material composition on the stepwise methane to methanol conversion over Cu-MOR: An operando XAS study. Catal. Today 2019, 336, 99-108. [CrossRef]

24. Borfecchia, E.; Pappas, D.K.; Dyballa, M.; Lomachenko, K.A.; Negri, C.; Signorile, M.; Berlier, G. Evolution of active sites during selective oxidation of methane to methanol over $\mathrm{Cu}-\mathrm{CHA}$ and $\mathrm{Cu}-\mathrm{MOR}$ zeolites as monitored by operando XAS. Catal. Today 2019, 333, 17-27. [CrossRef]

25. Olsbye, U.; Svelle, S.; Bjørgen, M.; Beato, P.; Janssens, T.V.W.; Joensen, F.; Bordiga, S.; Lillerud, K.P. Conversion of Methanol to Hydrocarbons: How Zeolite Cavity and Pore Size Controls Product Selectivity. Angew. Chem. Int. Ed. 2012, 51, 5810-5831. [CrossRef]

26. Cortés-Reyes, M.; Finocchio, E.; Herrera, C.; Larrubia, M.A.; Alemany, L.J.; Busca, G. A study of Cu-SAPO-34 catalysts for SCR of NOx by ammonia. Microporous Mesoporous Mater. 2017, 241, 258-265. [CrossRef]

27. Deka, U.; Juhin, A.; Eilertsen, E.A.; Emerich, H.; Green, M.A.; Korhonen, S.T.; Weckhuysen, B.M.; Beale, A.M. Confirmation of Isolated $\mathrm{Cu}^{2+}$ Ions in SSZ-13 Zeolite as Active Sites in $\mathrm{NH}_{3}$-Selective Catalytic Reduction. J. Phys. Chem. C 2012, 116, 4809-4818. [CrossRef]

28. Fickel, D.W.; Fedeyko, J.M.; Lobo, R.F. Copper Coordination in Cu-SSZ-13 and Cu-SSZ-16 Investigated by Variable-Temperature XRD. J. Phys. Chem. C 2010, 114, 1633-1640. [CrossRef] 
29. Borfecchia, E.; Beato, P.; Svelle, S.; Olsbye, U.; Lamberti, C.; Bordiga, S. Cu-CHA - a model system for applied selective redox catalysis. Chem. Soc. Rev. 2018, 47, 8097-8133. [CrossRef]

30. Pinilla-Herrero, I.; Olsbye, U.; Márquez-Álvarez, C.; Sastre, E. Effect of framework topology of SAPO catalysts on selectivity and deactivation profile in the methanol-to-olefins reaction. J. Catal. 2017, 352, 191-207. [CrossRef]

31. Woo, J.; Leistner, K.; Bernin, D.; Ahari, H.; Shost, M.; Zammit, M.; Olsson, L. Effect of various structure directing agents (SDAs) on low-temperature deactivation of Cu/SAPO-34 during NH3-SCR reaction. Catal. Sci. Technol. 2018, 8, 3090-3106. [CrossRef]

32. Vennestrøm, P.N.R.; Katerinopoulou, A.; Tiruvalam, R.R.; Kustov, A.; Moses, P.G.; Concepcion, P.; Corma, A. Migration of $\mathrm{Cu}$ Ions in SAPO-34 and Its Impact on Selective Catalytic Reduction of NOx with NH3. ACS Catal. 2013, 3, 2158-2161. [CrossRef]

33. Ipek, B.; Wulfers, M.J.; Kim, H.; Göltl, F.; Hermans, I.; Smith, J.P.; Booksh, K.S.; Brown, C.M.; Lobo, R.F. Formation of $\left[\mathrm{Cu}_{2} \mathrm{O}_{2}\right]^{2+}$ and $\left[\mathrm{Cu}_{2} \mathrm{O}\right]^{2+}$ toward C-H Bond Activation in Cu-SSZ-13 and Cu-SSZ-39. ACS Catal. 2017, 7, 4291-4303. [CrossRef]

34. Chen, P.; Root, D.E.; Campochiaro, C.; Fujisawa, K.; Solomon, E.I. Spectroscopic and Electronic Structure Studies of the Diamagnetic Side-On CuII-Superoxo Complex Cu(O2)[HB(3-R-5-iPrpz)3]: Antiferromagnetic Coupling versus Covalent Delocalization. J. Am. Chem. Soc. 2003, 125, 466-474. [CrossRef] [PubMed]

35. Leofanti, G.; Marsella, A.; Cremaschi, B.; Garilli, M.; Zecchina, A.; Spoto, G.; Bordiga, S.; Fisicaro, P.; Berlier, G.; Prestipino, C.; et al. Alumina-supported copper chloride 3. Effect of exposure to ethylene. J. Catal. 2001, 202, 279-295. [CrossRef]

36. Giordanino, F.; Vennestrom, P.N.R.; Lundegaard, L.F.; Stappen, F.N.; Mossin, S.; Beato, P.; Bordiga, S.; Lamberti, C. Characterization of Cu-Exchanged SSZ-13: A Comparative FTIR, UV-Vis, and EPR Study with Cu-ZSM-5 and Cu-beta with Similar Si/Al and Cu/Al Ratios. Dalton Trans. 2013, 42, 12741-12761. [CrossRef] [PubMed]

37. Bordiga, S.; Lamberti, C.; Bonino, F.; Travert, A.; Thibault-Starzyk, F. Probing zeolites by vibrational spectroscopies. Chem. Soc. Rev. 2015, 44, 7262-7341. [CrossRef] [PubMed]

38. Borfecchia, E.; Lomachenko, K.A.; Giordanino, F.; Falsig, H.; Beato, P.; Soldatov, A.V.; Bordiga, S.; Lamberti, C. Revisiting the Nature of $\mathrm{Cu}$ sites in the Activated Cu-SSZ-13 Catalyst for SCR reaction. Chem. Sci. 2015, 6, 548-563. [CrossRef]

39. Paolucci, C.; Parekh, A.A.; Khurana, I.; Di Iorio, J.R.; Li, H.; Albarracin Caballero, J.D.; Shih, A.J.; Anggara, T.; Delgass, W.N.; Miller, J.T.; et al. Catalysis in a Cage: Condition-Dependent Speciation and Dynamics of Exchanged Cu Cations in SSZ-13 Zeolites. J. Am. Chem. Soc. 2016, 138, 6028-6048. [CrossRef]

40. Martins, G.V.A.; Berlier, G.; Bisio, C.; Coluccia, S.; Pastore, H.O.; Marchese, L. Quantification of Brønsted Acid Sites in Microporous Catalysts by a Combined FTIR and NH3-TPD Study. J. Phys. Chem. C 2008, 112, 7193-7200. [CrossRef]

41. Giordanino, F.; Borfecchia, E.; Lomachenko, K.A.; Lazzarini, A.; Agostini, G.; Gallo, E.; Soldatov, A.V.; Beato, P.; Bordiga, S.; Lamberti, C. Interaction of $\mathrm{NH}_{3}$ with Cu-SSZ-13 Catalyst: A Complementary FTIR, XANES, and XES Study. J. Phys. Chem. Lett. 2014, 5, 1552-1559. [CrossRef]

42. Alayon, E.M.C.; Nachtegaal, M.; Bodi, A.; Ranocchiari, M.; van Bokhoven, J.A. Bis( $\mu$-oxo) Versus mono( $\mu$-oxo) Dicopper Cores in a Zeolite for Converting Methane to Methanol: An In Situ XAS and DFT Investigation. Phys. Chem. Chem. Phys. 2015, 17, 7681-7693. [CrossRef]

43. Llabrés i Xamena, F.X.; Fisicaro, P.; Berlier, G.; Zecchina, A.; Palomino, G.T.; Prestipino, C.; Bordiga, S.; Giamello, E.; Lamberti, C. Thermal Reduction of $\mathrm{Cu}^{2+}-$ Mordenite and Re-oxidation upon Interaction with $\mathrm{H}_{2} \mathrm{O}, \mathrm{O}_{2}$, and NO. J. Phys. Chem. B 2003, 107, 7036-7044. [CrossRef]

44. Palomino, G.T.; Bordiga, S.; Zecchina, A.; Marra, G.L.; Lamberti, C. XRD, XAS, and IR Characterization of Copper-Exchanged Y Zeolite. J. Phys. Chem. B 2000, 104, 8641-8651. [CrossRef]

45. Kaucky, D.; Dědeček, J.I.; Wichterlová, B. $\mathrm{Co}^{2+}$ ion siting in pentasil-containing zeolites II. $\mathrm{Co}^{2+}$ ion sites and their occupation in ferrierite. A VIS diffuse reflectance spectroscopy study. Micropor. Mesopor. Mater. 1999, 31, 75-87. [CrossRef]

46. Gao, F.; Walter, E.D.; Washton, N.M.; Szanyi, J.; Peden, C.H.F. Synthesis and evaluation of Cu/SAPO-34 catalysts for NH3-SCR 2: Solid-state ion exchange and one-pot synthesis. Appl. Catal. B 2015, 162, 501-514. [CrossRef] 
47. Alayon, E.M.C.; Nachtegaal, M.; Bodi, A.; van Bokhoven, J.A. Reaction Conditions of Methane-to-Methanol Conversion Affect the Structure of Active Copper Sites. ACS Catal. 2014, 4, 16-22. [CrossRef]

48. Mertens, M.M. Synthesis and Use of AEI Structure-Type Molecular Sieves. WO/2009/117186. U.S. Patent 7622417B2, 6 February 2009.

49. Bellet, D.; Gorges, B.; Dallery, A.; Bernard, P.; Pereiro, E.; Baruchel, J. A $1300 \mathrm{~K}$ furnace for in situ X-ray microtomography. J. Appl. Crystallogr. 2003, 36, 366-367. [CrossRef]

50. Bordiga, S.; Groppo, E.; Agostini, G.; Bokhoven, J.A.V.; Lamberti, C. Reactivity of Surface Species in Heterogeneous Catalysts Probed by In Situ X-ray Absorption Techniques. Chem. Rev. 2013, 113, 1736-1850. [CrossRef]

51. Ravel, B.; Newville, M. Athena, Artemis, Hephaestus: Data analysis for X-ray absorption spectroscopy using IFEFFIT. J. Synchrotron Radiat. 2005, 12, 537-541. [CrossRef] [PubMed]

(C) 2020 by the authors. Licensee MDPI, Basel, Switzerland. This article is an open access article distributed under the terms and conditions of the Creative Commons Attribution (CC BY) license (http://creativecommons.org/licenses/by/4.0/). 